\title{
EFFECT OF SEAWEED EXTRACTS AS FOLIAR SPRAY ON SUNFLOWER YIELD AND OIL CONTENT
}

\author{
Hanan E. Osman ${ }^{1}$ and Olfat M. A. Salem ${ }^{2}$ \\ 1. Botany and Microbiology Depart, Faculty of Science, Al-Azhar University \\ (Girls Branch). \\ 2. Botany and Microbiology Department, Faculty of Science, Helwan University.
}

\begin{abstract}
A field experiment was conducted, June 2009 to study the effects of foliar applications of different concentrations of seaweed extract of Ulva lactuca (Ulvaceae) and Gracilaria dendroides (Gracilariaceae) on nutrient uptake, growth and yield of sunflower plant. There were five treatment control and two concentration 0.4 and $0.6 \% \mathrm{w} / \mathrm{v}$ from each algal extract, this treatment applied at 3 times; first one at the seedling stage ( 20 days after sowing), the second at the flowering stage (40 days after sowing), while the third one before yield stage (70 days after sowing). Application of algal extract significantly increase fresh and dry weight of root and shoot, chlorophyll a, chlorophyll b and carotenoids rather than the control, especially with $0.6 \%$ extract of G. dendroides.

At harvest stage, application of seaweed significantly increase both root and shoot fresh and dry weight, plant height, head diameter, seed index (weight of 1000 seed), seed yield as compared to control. Also, the highest growth parameters were observed in plant treated by $0.6 \%$ extract of $G$. dendroides, except plant height.

Highest oil content was observed at $0.6 \%$ G. dendroides extract, followed with $0.6 \%$ U. lactuca extract application (34.05 and $30.55 \%$, respectively). The application of extract of $0.4 \%$ and $0.6 \%$ for both studied algae significantly increased seed yield of sunflower by $20.94,40.31,30.29$ and $28.73 \%$, respectively, compared to control.

Improved nutrient uptake ( $\mathrm{Na}$ and $\mathrm{K}$ ) was also observed with seaweed extract applications. Thus, foliar applications of seaweed extracts could be a promising option for yield enhancement and high oil yield production of sunflower plant.
\end{abstract}

Keywords: Gracilaria dendroides, Oil content, Sunflower, Ulva lactuca, Yield

\section{Introduction}

There is no doubt that increasing production of vegetable oils became a dire need in Egypt, especially our local production not exceed 150,000 ton in 2010, meanwhile the consumption will reach 820,000 ton (according to Specialized National Councils) i.e., the ratio of our self-sufficiency will not extend beyond 15 $\%$. 
Sunflower (Helianthus annus L.) is one of the most widely cultivated oil crops in the world and considered one of the promising oil crops in Egypt that could meet the oil needs.

The achievement of high grain and oil yields has been the main goal of sunflower production. In recent years, there has been an increasing demand for agricultural products with specific qualities (Siskos et al., 2001).

Fatty acid are classified into saturated and unsaturated fats, saturated tend to increase blood cholesterol levels, while unsaturated ones show the reverse direction, saturated fatty acids represent about $20 \%$ of the total fatty acid content of most plants, Sunflower especially contain $90 \%$ unsaturated fatty acid (Anderson and Beardall,1999).

Application of seaweed extract have been known for many years as soil fertilizers and plant growth supplements in agriculture giving beneficial effects including, increase in crop yield, fruit fresh weight, improved fruit yield, high chlorophyll levels in the plant leaves, improved nutrient uptake by the crops, enhancement of seed germination, plant resistance against stress conditions, reduced incidence of fungal disease and insect attack, and the reduction of the effect of water and salinity stress on plant (Zodape, 2001; Malaguti et al., 2002; Hu et al., 2004; Wang et al., 2005; El-Bakry et al., 2006 and Salah EI Din et al., 2008).

Liquid extracts obtained from seaweeds have gained importance as foliar sprays for several crops because the extract contains growth promoting hormones, cytokinins, trace elements, vitamins (Strik et $\boldsymbol{a l}$., 2004 and Mamatha $\boldsymbol{e t}$ al., 2007). It was also reported that seaweed extract exhibit hormone-like activities on plants but the measured levels of cytokinin or cytokinin-like substances were not high enough to account for all of the claimed effects of these extracts (Metting $\boldsymbol{e t}$ al., 1990). Moreover in the last two decades a number of studies have pointed out the antioxygenic activities of aqueous, ethanolic or lipid soluble extracts of seaweed (Le Tutour et al., 1998).

Seaweed extract develop tolerance to environment stress (Zhang and Schmidt, 2000; Zhang et al., 2003), increase nutrient uptake from soil (Turan and Köse, 2004). The beneficial effect of seaweed extract application is as a result of many components that may work synergistically at different concentrations, although the mode of action still remains unknown (Fornes $\boldsymbol{e t}$ al., 2002). In recent years, use of seaweed extracts have gained in popularity due to their potential use in organic and sustainable agriculture, as a means to avoid excessive fertilizer applications and to improve mineral absorption. Unlike, chemical fertilizers, extracts derived from seaweeds are biodegradable, non-toxic, non-polluting and non-hazardous to humans, animals and birds (Dhargalkar and Pereira, 2005). 
Seaweed extracts are now available commercially under different names, such as Maxicrop (Sea born), Algifert (marinure), Goemar GA14, Kelpak 66, Seaspray, Seasol, SM3, Cytex and Seacrop 16 (Gandhiyappan and Perumal, 2001). This proved that seaweed fertilizers are better than other fertilizers and are very economical.

The main objective of this study is to evaluate the application of different concentrations of two Egyptian marine seaweeds Ulva lactuca (Ulvaceae), and Gracilaria dendroides (Gracilariaceae) extract in enhancing the growth, yield, seed quality, oil content and nutrient uptake of sunflower grown in fields under normal conditions.

\section{Materials and Methods}

\section{Collection of Seaweeds}

$U$. lactuca and $G$. dendroides were collected from the coastal area of Mediterranean Sea at Alexandria and Baltim, Egypt, respectively, during June, 2008. The algal species were handpicked and washed thoroughly with seawater to remove all the unwanted impurities, adhering sand particles and epiphytes. Morphologically distinct thallus of algae was placed separately in new plastic bags and kept in an ice box containing slush ice and transported to the laboratory. Samples were washed thoroughly using tap water to remove the salt from the surface of the sample. The water was drained off and the algae were spread on blotting paper to remove excess water.

\section{Preparation of Seaweed Liquid Fertilizers}

One $\mathrm{kg}$ of seaweed was cut into small pieces and boiled separately with $1 \mathrm{~L}$ of distilled water for an hour and filtered. The filtrate was taken as $100 \%$ concentration of the seaweed extract then different concentrations from the filtrate were prepared using distilled water (Bhosle et al., 1975).

\section{Experimental Site and Treatments}

The field experiment was conducted during the summer season of 2009 in a cultivated area located at Roken Farouk, Helwan Governorate, Egypt. It was irrigated from River Nile.

The soil of the site was clay loam with $\left(\mathrm{EC} 1.85 \mathrm{dsm}^{-1}\right),(\mathrm{pH} 7.3)$, contained $2.05 \%$ organic matter, $0.11 \%$ nitrogen, $0.43 \mathrm{M} \mathrm{mol} / \mathrm{L}$ potassium, and $4.69 \mathrm{M} \mathrm{mol} / \mathrm{L}$ sodium. The analysis of irrigation water showed that EC value was $0.52 \mathrm{dsm}^{-1}$ and $\mathrm{pH} 7.6$.

The treatments in this experiment was 5 treatments, viz, 0.0 (control), 0.4 and $0.6 \%$ for $U$. lactuca and G. dendroides .Three sprays of both tested seaweed were applied, first one after 20 days from sowing, the second after 40 days from sowing while the third one after 70 days from sowing.

Egyptian J. of Phycol. Vol. 12, $2011 \quad 59$ - 


\section{Selection of Crop Plant}

The crop plant was sunflower (Vidok) belonging to the family Asteraceae. The seeds were obtained from Agricultural Research Center (ARC), Giza, Egypt. The seeds with uniform size, color and weight were chosen for the experimental purpose.

\section{Plant Sampling and Chemical Analyses}

Samples of fifteen plants were taken from each plot of sunflower plant after 45, and 65 days from sowing to determine their growth parameters: root and shoot fresh and dry weight $\left(\mathrm{g} \mathrm{plant}^{-1}\right)$, chlorophyll a, b and carotenoids.

Also, at yield stage, the same number were taken to estimate the root and shoot fresh and dry weight $\left(\mathrm{g}_{\text {plant }}{ }^{-1}\right)$, plant height, disk diameter $(\mathrm{cm})$, seed yield $\left(\mathrm{kg} \mathrm{Fed}^{-1}\right)$, seed index (1000 seed weight), seed oil \%, oil yield (kg Fadden $\left.{ }^{-1}\right)$, seed fatty acids content, potassium and sodium content of seed.

Chlorophylls $(\mathrm{a}, \mathrm{b})$ and carotenoids were determined in sunflower leaves in two growth stages; 45 days and 65 days according to the method of Metzner et al. (1965).

The chemical composition were determined by taking samples of fresh matter (100g), and oven dried at $65^{\circ} \mathrm{C}$ to a constant weight (AOAC, 2000). Samples were milled to fine powder and used for the chemical analyses. Sodium (Na) and Potassium (K) contents of plant samples is estimated by flamephotometer in an acid digestion solution according to AOAC (2000).

Seed oil was determined after extraction with Soxhelt`s apparatus using hexan as an organic solvent according to AOAC (2000). Also, extraction of lipid was conducted by using chloroform methanol $(2: 2 \mathrm{v} / \mathrm{v})$ to extract the lipid (AOAC, 2000).

\section{Statistical Analysis}

The seeds were sown in plots (in hills, each plot contains 5 hills, interspaces between each two hills was $60 \mathrm{~cm})$ each plot was $10.5 \mathrm{~m}^{2}(3.5 \mathrm{~m}$ length and $3 \mathrm{~m}$ width $)=1 / 400$ faddan (faddan $=\mathrm{fad}=0.42 \mathrm{ha}$ ). The experiment was laid out in randomized complete block design with three replicates. Pooled data subjected to analyses by M-STAT C, (Russell, 1991). The differences among the means were performed by least significant difference (L.S.D.) at 5\% level. At the same time, the data were presented as mean \pm standard deviation of three replicates tests, and the data were analyzed with EXCEL 2007 for Win.

\section{Results and Discussion}

The biochemical analysis of the two algal species showed the presence of plant growth regulators with varied amount in auxins \{Indole-3-acetic acid (IAA), Abscisic acid (ABA)\}, gibberellins \{Gibberellic acid (GA3)\} and cytokinins 
\{(Kinetin, Zeatin) and Benzyl adenine $\}$. The beneficial effect of seaweed extract appeared to be due to these plant growth regulators present in the extract as mentioned by Yvin (1994).

Plant growth regulators in both tested seaweed species found in Table 1. The data showed that the higher content of Gibberellic acid (GA3), Indole-3acetic acid (IAA), Abscisic acid (ABA), and Benzyladenine (BA) was detected in $U$. lactuca, while , G. dendroides had the higher kinetin and Zeatin (Table 1).

Table (1): The plant Growth Regulators Present in Seaweed Liquid Fertilizer of Ulva lactuca and Gracilaria dendroides.

\begin{tabular}{|c|c|c|c|c|c|c|}
\hline Algae type & $\begin{array}{c}\mathbf{G A} \mathbf{A}_{3} \\
\text { mg } 100 \mathrm{~g}^{-1} \\
\end{array}$ & $\begin{array}{c}\text { IAA } \\
\text { mg } 100 \mathrm{~g}^{-1} \\
\end{array}$ & $\begin{array}{c}\text { ABA } \\
\text { mg } 100 \mathrm{~g}^{-1} \\
\end{array}$ & $\begin{array}{c}\text { Kinetin } \\
\mu \mathrm{g} 100 \mathrm{~g}^{-1}\end{array}$ & $\begin{array}{c}\text { Zeatin } \\
\mu \mathrm{g} 100 \mathrm{~g}^{-1}\end{array}$ & $\begin{array}{c}\text { BA } \\
\mu \mathrm{g} 100 \mathrm{~g}^{-1} \\
\end{array}$ \\
\hline G. dendroides & $54.20 \pm 0.88$ & $1.54 \pm 0.15$ & $0.10 \pm 0.02$ & $415.80 \pm 3.56$ & $167.22 \pm 4.78$ & $33.99 \pm 1.45$ \\
\hline U. lactuca & $135.75 \pm 2.34$ & $7.12 \pm 0.2$ & $0.37 \pm 0.08$ & $353.15 \pm 8.11$ & $35.88 \pm 2.33$ & $44.38 \pm 1.89$ \\
\hline
\end{tabular}

$\mathrm{GA}_{3}=$ Gibberellic acid; IAA = Indole-3-acetic acid $\mathrm{ABA}=$ Abscisic acid BA = Benzyl adenine

\section{Effect of Seaweed Extract on Growth Parameters and Pigment at First and} Second Stage

Application of seaweed extract significantly increase all the growth parameters and pigment content of sunflower plant at first and second stage as compared to the control (Table 2).

At first stage (45 days from plantation) the highest root fresh and dry weight were recorded in plant treated with $0.6 \%$ G. dendroides $(17.33$ and $4.53 \mathrm{~g}$ plant $^{-1}$, respectively). The highest shoot fresh and dry weights were detected in sunflower plant treated with $0.6 \%$ G. dendroides $\left(296\right.$ and $52.83 \mathrm{~g} \mathrm{plant}^{-1}$, respectively). The same trend was observed at the second stage, the highest fresh and dry weights of both root and shoot were detected in sunflower treated with 0.6 $\%$ G. dendroides (114.6, 22.40, 650 and $130.66 \mathrm{~g} \mathrm{plant}^{-1}$, respectively).

These finding coincide with those of earlier studies carried out on marigold (Russo et al., 1994 and Thirumaran et al., 2009) where there was an increase in vegetative growth by the application of seaweed extract. Similar results were also observed in Cajanus cajan (L.). (Mohan et al., 1994) and Vigna sinensis L. (Sivasankari et al., 2006). The increase of these crops growth parameters may be due to the presence of some growth promoting substances present in the seaweed extract (Mooney and Van Staden, 1986; Blunden, 1991). In addition, the growth enhancing potential of the seaweed extract might be attributed to the presence of macro and micronutrients. 
Table (2): Effect of Seaweed Liquid Fertilizer (SLF) on Root and Shoot Fresh and Dry Weight (g plant ${ }^{1}$ ) and Pignent Contents ( $\mathrm{mg} \mathrm{g}^{-1}$ fresh wt) of Sunflower after 45 and 65 Days from Plantation.

\begin{tabular}{|c|c|c|c|c|c|c|c|}
\hline \multirow{3}{*}{ Treatment } & \multicolumn{2}{|c|}{ Root } & \multicolumn{2}{|c|}{ Shoot } & \multicolumn{2}{|c|}{ Chlor ophyll } & \multirow{3}{*}{ Carotenoids } \\
\hline & \multirow{2}{*}{$\begin{array}{l}\text { Fresh wt. } \\
\text { g plant }^{-1}\end{array}$} & \multirow{2}{*}{$\begin{array}{l}\text { Dry wt. } \\
\text { g plant }\end{array}$} & \multirow{2}{*}{$\begin{array}{l}\text { Dry wt. } \\
\text { g plant }\end{array}$} & \multirow{2}{*}{$\begin{array}{l}\text { Fresh wt. } \\
\text { g plant }^{-1}\end{array}$} & a & b & \\
\hline & & & & & \multicolumn{2}{|c|}{ mg g fresh wt } & \\
\hline \multicolumn{8}{|c|}{45 Days from Plantation } \\
\hline Control & $9.093 \pm 0.25$ & $3.23 \pm 0.03$ & $215 \pm 48.22$ & $33.33 \pm 2.01$ & $4.48 \pm .50$ & $2.09 \pm 0.11$ & $2.02 \pm 0.20$ \\
\hline $0.4 \% \mathrm{G}$ & $14.33 \pm 0.80$ & $3.90 \pm 0.10$ & $274 \pm 25.03$ & $49.6 \pm 10.02$ & $7.07 \pm 0.20$ & $3.02 \pm 0.27$ & $2.87 \pm 0.04$ \\
\hline $0.6 \% \mathrm{G}$ & $17.33 \pm 1.57$ & $4.53 \pm 0.11$ & $296 \pm 11.55$ & $52.83 \pm 2.84$ & $6.23 \pm .17$ & $3.44 \pm 0.27$ & $2.80 \pm 0.19$ \\
\hline $0.4 \% \mathrm{U}$ & $12.33 \pm 2.10$ & $3.26 \pm 0.09$ & $285 \pm 5.00$ & $48.16 \pm 2.47$ & $7.40 \pm 53$ & $2.65 \pm .70$ & $3.10 \pm 0.82$ \\
\hline $0.6 \% \mathrm{U}$ & $12.66 \pm 2.23$ & $3.60 \pm 0.08$ & $292 \pm 7.55$ & $50.33 \pm 0.58$ & $6.03 \pm 39$ & $3.36 \pm 1.84$ & $1.90 \pm 0.51$ \\
\hline L.S.D. 0.05 & 2.39 & 0.11 & 38.00 & 10.79 & 1.01 & 0.66 & 0.74 \\
\hline \multicolumn{8}{|c|}{65 Days from Plantation } \\
\hline Control & $64.66 \pm 5.51$ & $15.16 \pm 0.67$ & $440 \pm 36.06$ & $70.00 \pm 3.00$ & $3.73 \pm 0.91$ & $1.73 \pm 0.14$ & $0.62 \pm 0.06$ \\
\hline $0.4 \% \mathrm{G}$ & $100.33 \pm 0.02$ & $20.66 \pm 0.58$ & $454 \pm 22.05$ & $89.96 \pm 3.66$ & $4.05 \pm 0.36$ & $2.49 \pm 0.02$ & $1.12 \pm 0.20$ \\
\hline $0.6 \% \mathrm{G}$ & $114.66 \pm 24.25$ & $22.40 \pm 2.41$ & $650 \pm 70.89$ & $130.66 \pm 16.86$ & $4.34 \pm 0.07$ & $2.84 \pm 0.84$ & $1.17 \pm 0.53$ \\
\hline $0.4 \% \mathrm{U}$ & $108.00 \pm 5.03$ & $21.70 \pm 1.87$ & $587 \pm 20.40$ & $106.13 \pm 29.35$ & $5.63 \pm 1.24$ & $2.47 \pm 0.94$ & $1.90 \pm 1.20$ \\
\hline $0.6 \% \mathrm{U}$ & $93.33 \pm 15.28$ & $16.10 \pm 1.08$ & $616 \pm 35.12$ & $121.66 \pm 8.19$ & $6.28 \pm 0.49$ & $2.61 \pm 0.22$ & $2.54 \pm 0.86$ \\
\hline L.S.D. 0.05 & 27.46 & 4.55 & 79.00 & 23.76 & 0.47 & 0.11 & 0.47 \\
\hline
\end{tabular}

Generally application of seaweed extract significantly increased the pigment contents of sunflower. The first stage, the highest chlorophyll a and carotenoids were detected in sunflower plant treated with $0.4 \%$ U. lactuca $(7.40$ and $3.10 \mathrm{mg} \mathrm{g}^{-1}$, respectively). While the highest chlorophyll $\mathrm{b}$ was detected in plant treated with $0.6 \%$ G. dendroides $\left(3.44 \mathrm{mg} \mathrm{g}^{-1}\right)$.

Meanwhile, in second stage, the highest chlorophyll a and carotenoids were recorded in plant treated with $0.6 \%$ U. lactuca $\left(6.28\right.$ and $2.54 \mathrm{mg} \mathrm{g}^{-1}$, respectively). While the highest chlorophyll $\mathrm{b}$ was recorded in plant treated with $0.6 \%$ G. dendroides $\left(2.84 \mathrm{mg} \mathrm{g}^{-1}\right)$.

Whapham et al. (1993) observed that the application of SLF of Ascophyllum nodosum increased the chlorophyll of cucumber cotyledons and tomato plant. This increase was due to the betaines which seaweed contains. Also, Gerald et al. (1997) suggested strongly that the enhanced leaf chlorophyll content of plants treated with seaweed extract is dependent on the betaines present.

\section{Effect of Seaweed Extract on Growth Parameters and Yield at Harvest Stage}

The effect of Seaweed Liquid Fertilizer (SLF) on fresh and dry weight of root and shoot, plant height, head diameter, seed index, and seed yield at harvest stage were presented in Table (3). 
Application of seaweed significantly increase both root and shoot fresh and dry weight, plant height, head diameter, seed index (weight of 1000 seed), seed yield as compared with control. Also, the highest growth parameters were observed in plant treated $0.6 \%$ G. dendroides, except plant height (Table 3).

Table (3): The Effect of Seaweed Extract on Growth Parameters of Sunflower at Yield Stage.

\begin{tabular}{|c|c|c|c|c|c|c|c|c|}
\hline \multirow{2}{*}{ Treatment } & \multicolumn{2}{|c|}{ Root } & \multicolumn{2}{|c|}{ Shoot } & \multirow{2}{*}{$\begin{array}{c}\text { Plant Height } \\
\text { ci. }\end{array}$} & \multirow{2}{*}{$\begin{array}{c}\text { Heal } \\
\text { Dianneter } \\
\text { an. }\end{array}$} & \multirow[b]{2}{*}{ Seed Index } & \multirow{2}{*}{$\begin{array}{l}\text { Seed Yiell } \\
\text { Kg fad }^{1}\end{array}$} \\
\hline & $\begin{array}{l}\text { Fresh wt. } \\
\text { g phant }{ }^{-1}\end{array}$ & \begin{tabular}{|l|} 
Dry wt. \\
o plant
\end{tabular} & $\begin{array}{l}\text { Fresh wt. } \\
\text { o plantit }\end{array}$ & $\begin{array}{l}\text { Drywt. } \\
\text { g plant }{ }^{1}\end{array}$ & & & & \\
\hline Control & $84,33 \pm 5.86$ & $19.17 \pm 1.04$ & $490.00 \pm 5,77$ & $85.33 \pm 5.03$ & $124.33 \pm 6.66$ & $14.39 \pm 0.58$ & $62.00 \pm 10.23$ & $3442.36 \pm 88.90$ \\
\hline $0.4 \% G$ & $119.33 \pm 1.15$ & $23.47 \pm 0.92$ & $535.00 \pm 49.36$ & $103.67 \pm 8.14$ & $143.67 \pm 3.51$ & $10,30 \pm 1.00$ & $84.00 \pm 11.89$ & $4163.06 \pm 121.1$ \\
\hline $0.6 \% \mathrm{G}$ & $132.00 \pm 1553$ & $2737 \pm 3.27$ & $763.00 \pm 63.51$ & $195.00 \pm 13.75$ & $167.33 \pm 13.01$ & $19.51 \pm 1.05$ & $100.00 \pm 9.78$ & $4830.00 \pm 130.1$ \\
\hline $0.4 \% \mathrm{U}$ & $113.33 \pm 7.21$ & $26.87 \pm 4.27$ & $650.00 \pm 43.59$ & $145.00 \pm 15.00$ & $170.67 \pm 16.17$ & $16.91 \pm 0.58$ & $90.00 \pm 12.45$ & $4485.00 \pm 129.88$ \\
\hline $0.6 \% \mathrm{U}$ & $127,33 \pm 15,28$ & $26.20 \pm 1.71$ & $676.00 \pm 77.26$ & $160.00 \pm 15.62$ & $154.00 \pm 15.10$ & $17.66 \pm 1.15$ & $88.00 \pm 10.98$ & $443139 \pm 119.18$ \\
\hline $\mathrm{L} .5 . \mathrm{S} \cdot \mathrm{D} \cdot 0.05$ & 19.78 & 4.62 & 83.00 & 22.57 & 17.38 & 1.14 & 13.00 & 134.53 \\
\hline
\end{tabular}

$G=G$. lendroides, whereas, $\mathrm{V}=\mathrm{U}$. inctucu $\mathrm{Wt}=$ weight

The highest fresh and dry weight of roots and shoots were recorded in sunflower treated with $0.6 \%$ G. dendroides, the same trend of the first two stages (45 and 65 days after planting). Meanwhile, the highest plant height was recorded in sunflower plant treated with $0.4 \%$ U. lactuca $(170.67 \mathrm{~cm})$ followed by $0.6 \% \mathrm{G}$ $(167.33 \mathrm{~cm})$ Table (3). The biggest head diameter was observed in plant treated with $0.6 \%$ G. dendroides $(19.51 \mathrm{~cm})$, followed by $0.6 \%$ U. lactuca $(17.66 \mathrm{~cm})$. Seed index (weight of 1000 seed), treatment by $0.6 \%$ G. dendroides gave the highest $(100 \mathrm{~g})$, followed by $0.4 \% \mathrm{U}$. lactuca $(90 \mathrm{~g})$ they increased by 61.29 and $45.16 \%$ respectively as compared with the control (Table 3 ).

Seed yield $\left(\mathrm{Kg} \mathrm{fed}^{-1}\right)$ was observed highest at $0.6 \%$ G. dendroides which was significantly than other treatments. The application of $0.4 \%$ and $0.6 \%$ for both algal species significantly increased seed yield of sunflower by 20.94, 40.31, 30.29 and $28.73 \%$, respectively, as compared with control.

In this study, increased vegetative growth, head diameter, and seed index due to seaweed extract application resulted in greater overall production of seed 
yield. Similarly, Rama Rao (1991) obtained increased yield and improvement in the quality of Zizyphus mauritiana $L$. with foliar applications of seaweed extract.

Further, these findings also coincide with Rathore et al. (2009) they found that applications of different concentrations of seaweed extract (prepared from Kappaphycus alvarezii) increase plant height, number of pods per plant, number of grains per plant, number of branches, and yield of soybean plant.

Effect of Seaweed Extract on Chemical Composition and Oil Content of Sunflower

Application of seaweed significantly increased oil content, oil yield, K, $\mathrm{Na}$ and crude protein of sunflower seed as compared with control (Table 4). The highest oil content, oil yield, $\mathrm{K}$ and crude protein were detected in $0.6 \% \mathrm{G}$. dendroides meanwhile, the highest $\mathrm{Na}$ content was found in sunflower treated with $0.4 \%$ U. lactuca.

Oil content was observed highest at $0.6 \%$ G. dendroides followed with $0.6 \%$ U. lactuca application (34.05 and 30.55\%, respectively) increase over the control. The effect of the treatments on oil yield depicted a similar trend, where highest oil yield was observed at $0.6 \%$ G. dendroides, which was significantly than other treatments. Application of $0.4 \%, 0.6 \%$ for both species studied significantly increased oil yield by $40.22,88.02,61.02$ and $68.06 \%$, respectively, as compared with control. The highest $\mathrm{K}$ content and crude protein was found in plant treated with $0.6 \%$ G. dendroides were reached $46.33 \mathrm{mg} \mathrm{Kg}^{-1}$ and $37.74 \%$, respectively.

Table (4): The Effect of Seaweed Extract on Oil Content, Potassium, Sodium and crude Protein of Sunflower Seed.

\begin{tabular}{|c|c|c|c|c|c|}
\hline Treatment & $\begin{array}{c}\text { Oil } \\
\text { content } \\
\%\end{array}$ & $\begin{array}{l}\text { Oil yield } \\
\text { Kg fad. }^{-1}\end{array}$ & $\begin{array}{c}\mathrm{K} \\
\mathrm{mg} \mathrm{Kg}^{-1}\end{array}$ & $\begin{array}{c}\mathrm{Na} \\
\mathrm{mg} \mathrm{Kg}^{-1}\end{array}$ & $\begin{array}{c}\text { Crude } \\
\text { Protein } \\
\% \\
\end{array}$ \\
\hline Control & $\begin{array}{c}31.75 \pm \\
0.89\end{array}$ & $\begin{array}{c}1092.95 \pm \\
59.12\end{array}$ & $\begin{array}{c}38.25 \pm \\
0.98\end{array}$ & $8.67 \pm 0.12$ & $\begin{array}{c}24.35 \pm \\
1.88\end{array}$ \\
\hline $0.4 \% \mathrm{G}$ & $\begin{array}{c}36.83 \\
0.90\end{array}$ & $\begin{array}{c}1533.25 \pm \\
77.34\end{array}$ & $\begin{array}{c}41.08 \pm \\
1.30\end{array}$ & $\begin{array}{c}10.70 \pm \\
0.25\end{array}$ & $\begin{array}{c}32.15 \pm \\
1.96\end{array}$ \\
\hline $0.6 \% \mathrm{G}$ & $\begin{array}{c}42.56 \pm \\
0.108\end{array}$ & $\begin{array}{c}2055.65 \\
\mathbf{5 6 . 3 9}\end{array}$ & $\begin{array}{c}46.33 \pm \\
1.12\end{array}$ & $\begin{array}{c}12.73 \pm \\
0.30\end{array}$ & $\begin{array}{c}37.74 \pm \\
1.57\end{array}$ \\
\hline $0.4 \% \mathrm{U}$ & $\begin{array}{c}39.24 \pm \\
1.10\end{array}$ & $\begin{array}{c}1759.91 \pm \\
66.78\end{array}$ & $\begin{array}{c}45.70 \pm \\
1.76\end{array}$ & $\begin{array}{c}14.07 \pm \\
0.36\end{array}$ & $\begin{array}{c}35.12 \pm \\
0.98\end{array}$ \\
\hline $0.6 \% \mathrm{U}$ & $\begin{array}{c}41.45 \pm \\
0.79\end{array}$ & $\begin{array}{c}1836.81 \pm \\
78.00\end{array}$ & $\begin{array}{c}42.45 \pm \\
1.49\end{array}$ & $\begin{array}{c}13.67 \pm \\
0.39\end{array}$ & $\begin{array}{c}36.86 \pm \\
1.09\end{array}$ \\
\hline L.S.D. 0.05 & 1.15 & 81.29 & 1.83 & 0.40 & 2.15 \\
\hline
\end{tabular}

$\mathrm{G}=G$. dendroides. whereas, $\mathrm{U}=U$. lactuca. 
The results confirm those previously reported by Crouch et al. (1990) who noted increased uptake of $\mathrm{Mg}, \mathrm{K}$ and $\mathrm{Ca}$ in lettuce with seaweed application. Nelson and Van Staden (1984), Turan and Köse (2004) and Mancuso et al. (2006) also observed increased uptake of $\mathrm{N}, \mathrm{P}, \mathrm{K}$ and $\mathrm{Mg}$ in grapevines and cucumber with application of seaweed extract. Mancuso et al. (2006) add that the presence of marine bioactive substances in seaweed extract improves stomata uptake efficiency in treated plants compared to non-treated plants.

Biostimulants, even those containing minerals, are not able to supply all the essential nutrients in the quantities required by plants (Schmidt et al., 2003) but may enhance root growth of plant subjected to stress possibly by increasing the antioxidant defense system (Zhang and Schmidt, 2000). In addition to proper mineral fertilization, biostimulants can enhance the effectiveness of fertilizers as well as nutrient utilization from soil (Frankenberger and Arshad, 1995).

\section{Effect of Seaweed Extract on Fatty Acid Picture of Sunflower Seed}

Fatty acids are a carboxylic acids with long hydrocarbon chains, the hydrocarbon chain length vary from 10-30 carbons (most usual is 12-18). There are two groups of fatty acids saturated and unsaturated. The term unsaturated refers to the presence of one or more double bonds between carbons as in alkenes. A saturated fatty acid has all bonding positions between carbons occupied by hydrogen (Izquierdo and Aguirrezabal, 2008).

The fatty acids picture of sunflower plants are presented in Table 5. No clear trend was observed. The plant treated with $0.6 \mathrm{G}$. dendroides achieved the highest values in stearic, archidic and arachidonic, while the highest value of palmitic and palmitelaidic were recorded in sunflower treated with $0.4 \% G$. dendroides. High oleic and linolenic was recorded in plant treated with $0.4 \% U$. lactuca.

It is a common knowledge that the suitability of sunflower oil for different uses and so its commercial value depends mainly on the proportions of linoleic and oleic acids, both of which account for about $90 \%$ of the total fatty acids (FAs) of triacylglycerols. The unsaturation ratio (C18:1/C18:2) of the oil, however, is undoubtedly related to the growing environment and commonly it increases strongly in standard hybrids and less in high-oleic ones in relation to air thermal regime during grain lipid synthesis (Pereyra-Irujo and Aguirrezabal, 2007; Izquierdo and Aguirrezabal, 2008).

Oil concentration and fatty acid composition, especially oleic and linoleic fatty acids, of oil from sunflower varies greatly mainly as a response to temperature during seed development (Seiler, 1986). The suitability for alternative uses of sunflower oil is determined mainly by fatty acid composition and the amount of antioxidants. Oxidative stability, which delays the loss of nutritional value and the development of unpleasant flavors, depends on the proportion of oleic acid (18:1) and the amount of antioxidants, mainly aEgyptian J. of Phycol. Vol. 12, 2011 -65 - 
tocopherol (Cabrini et al., 2001). From the point of view of human health, polyunsaturated acids, such as linoleic acid (18:2), are essential to mammals and have a potent hypocholesterolemic effect (Kris-Etherton and Yu, 1997), thus lowering the risk of cardiovascular disease.

Table (5): The Effect of Seaweed Extract on Fatty Acid Picture (\%) of Sunflower Seed.

\begin{tabular}{|l|c|c|c|c|c|c|c|c|c|}
\hline Treattnent & $\begin{array}{c}\text { Myristic } \\
14: 0\end{array}$ & $\begin{array}{c}\text { Palmitic } \\
16: 0\end{array}$ & $\begin{array}{c}\text { Palmitelaidic } \\
16: 1\end{array}$ & $\begin{array}{c}\text { Steanic } \\
18: 2\end{array}$ & $\begin{array}{c}\text { Oleic } \\
18: 1\end{array}$ & $\begin{array}{c}\text { Linoleic } \\
18: 2\end{array}$ & $\begin{array}{c}\text { Lionlenic } \\
18: 3\end{array}$ & $\begin{array}{c}\text { Arclidic } \\
20: 0\end{array}$ & $\begin{array}{c}\text { Araclidonic } \\
20: 4\end{array}$ \\
\hline \hline Control & $0.66 \pm 0.08$ & $8.07 \pm 0.19$ & $1.74 \pm 0.10$ & $1.98 \pm 0.15$ & $72.41 \pm 1.12$ & $4.14 \pm 0.11$ & $0.14 \pm 0.01$ & $5.31 \pm 0.12$ & $1.48 \pm 0.07$ \\
\hline $0.4 \% \mathrm{G}$ & $0.58 \pm 0.06$ & $9.55 \pm 0.23$ & $3.91 \pm 0.13$ & $1.58 \pm 0.12$ & $65.82 \pm 1.34$ & $3.24 \pm 0.09$ & $0.14 \pm 0.02$ & $5.30 \pm 0.16$ & $2.76 \pm 0.09$ \\
\hline $0.6 \% \mathrm{G}$ & $0.57 \pm 0.05$ & $9.37 \pm 0.20$ & $3.00 \pm 0.08$ & $2.17 \pm 0.16$ & $66.98 \pm 0.98$ & $2.73 \pm 0.14$ & $0.12 \pm 0.01$ & $5.62 \pm 0.15$ & $3.15 \pm 0.10$ \\
\hline $0.4 \% \mathrm{U}$ & $0.39 \pm 0.04$ & $6.14 \pm 0.11$ & $1.43 \pm 0.07$ & $1.07 \pm 0.09$ & $76.53 \pm 0.1 .20$ & $6.98 \pm 0.13$ & $0.14 \pm 0.01$ & $2.25 \pm 0.09$ & $1.25 \pm 0.08$ \\
\hline $0.6 \% \mathrm{U}$ & $0.82 \pm 0.08$ & $7.69 \pm 0.20$ & $3.03 \pm 0.15$ & $1.71 \pm 0.10$ & $72.17 \pm 1.09$ & $3.18 \pm 0.08$ & $0.14 \pm 0.01$ & $2.65 \pm 0.08$ & $1.82 \pm 0.07$ \\
\hline \hline & 0.05 & 0.26 & 0.16 & 0.18 & 1.44 & 0.16 & 0.02 & 0.18 & 0.12 \\
\hline
\end{tabular}

$G=G$. dendroides, whereas, $\mathrm{U}=\mathrm{U}$. lactuca.

It could be concluded that applying seaweed extract can be a powerful and environmental friendly approach to improve plant growth and increase sunflower yield and oil content.

Both seaweed tested were effective in enhancing growth parameters, yield, nutrient uptake and oil content as compared to control. But the extract from $G$. dendroides was found to be promising in possessing fertilizer activity as compared to $U$. lactuca. It is probably due to the presence of growth promoting hormones and nutrients in more quantities in the G. dendroides. Seaweed liquid fertilizer can be applied to various crop plants in order to enrich the nutrient content of the soil and intern to increase the growth and yield of cultivated plants.

\section{References}

AOAC. (2000). Official Methods of Analysis of the Association of Official Analytical Chemist. $14^{\text {th }}$ ed Washington, D.C.

Anderson, J.W. and Beardall, J. (1999). Molecular activities of plant cells. An Introduction to plant chemistry. Blackwell Scientific Publications, Oxford, London, Paris.

Bhosle, N.B.; Untawale, A.G. and Dhargalker, V.K. (1975). Effect of seaweed extract on growth of Phaseolus vulgaris. Indian J. Mar. Sci., 4:208-210.

Blunden, G. (1991). Agricultural uses of seaweeds and seaweed products. In: Guiry, M.D., Blunden, G. (Eds.), Seaweed Resources in Europe: Uses and Potential. John Wiley and Sons, Chichester, pp. 65-81. 
Cabrini, L.; Barzanti, V.; Cipollone, M.; Fiorentini, D.; Grossi, G.; Tolomelli, B.; Zambonin, L. and Landi, L. (2001). Antioxidants and total peroxyl radical-trapping ability of olive and seed oils. J. Agric. Food Chem., 49:6026-6032.

Crouch, I. J.; Beckett, R. P. and Van Staden, J. (1990). Effect of seaweed concentrate on the growth and mineral nutrition of nutrient stress lettuce. Journal of Applied Phycology, 2:269-272.

Dhargalkar, V. K. and Pereira, N. (2005). Seaweed: promising plant of the millennium. Science and Culture, 71: 60-66.

Dorrell, D. G. (1978). Processing and utilization of oilseed sunflower. In: Carter, J.F. (Ed.), Sunflower Science and Technology. Crop Science Society of America, Madison, WI, USA, pp. 407-436.

Dorrell, D. G. and Vick, B. A. (1997). Properties and processing of oilseed sunflower. In: Schneiter, A.A. (Ed.), Sunflower Technology and Production. Crop Science Society of America, Madison, WI, USA, pp. 709-745.

El-Bakry, A. A.; Salah El Din, R. A.; Ghazi, S. M. and Abdel Hamid, O. M. (2006). Effect of some seaweed extracts on the growth and yield of Wheat (Triticum vulgare L.). Egypt. J. Biotech., 24: 195-209.

Fornes, F.; Sánchez-Perales, M. and Guadiola, J. L. (2002). Effect of a seaweed extract on the productivity of 'de Nules' Clementine mandarin and navelina orange. Botanica Marina, 45:486-489.

Frankenberger, Jr. W.T. and Arshad, M. (1995). Phytohormones in Soils. Microbial Production and Function. Marcel Dekker Inc., New York, US. ISBN:0814794427, Pages 503.

Gandhiyappan, K. and Perumal, P. (2001). Growth promoting effect of seaweed liquid fertilizer (Enteromorpha intestinalis) on the sesame crop plant. Seaweed Res. Utiln., 23 (1\&2): 23-25.

Gerald, B.; Teifryn, J. and Yan-Wen, L. (1997). Enhanced leaf chlorophyll levels in plants treated with seaweed extract. J. Appl. Phycology, 8: 535543.

Hu, X.; Jiang, X.; Hwang, H.; Liu, S. and Guan, H. (2004). Promotive effects of alginate-derived oligosaccharide on maize seed germination. J. Appl. Phycology, 16: 73-76.

Izquierdo, N.G. and Aguirrezabal, L.A.N. (2008). Genetic variability in the response of fatty acid composition to minimum night temperature during grain filling in sunflower. Field Crops Res., 106:116-125.

Le Tutour, B.; Benslimane, F.; Gouleau, M. P.; Gouygou, J. P.; Saadan, B.; Quemeneur, F. (1998). Antioxidant and pro-oxidant activities of the brown algae, Laminaria digitata, Himanthalia elongata, Fucus vesiculosus, Fucus serratus and Ascophyllum nodosum. Journal of Applied Phycology, 10:121-129. 
Kris-Etherton, P. M. and Yu, S. (1997). Individual fatty acid effects on plasma lipids and lipoproteins: human studies. Am. J. Clin. Nutr., 65:1628S$1644 S$.

Malaguti, D.; Rombola, A. D.; Gerin, M.; Simoni, G.; Tagliavini, M. and Marangoni, B. (2002). Effect of seaweed extract-based leaf spray on the mineral status yield and fruit quality of apple. Acta Hort., 594: 357-359.

Mamatha, B. S.; Namitha, K. K.; Senthil, A.; Smitha, J. and Ravishankar, G. A. (2007). Studies on use of Enteromorpha in snack food. Food Chemistry, 101:1707-1713.

Mancuso, S.; Azzarello, E.; Mugnai, S. and Briand, X. (2006). Marine bioactive substances (IPA extract) improve foliar ion uptake and water tolerance in potted Vitis vinifera plants. Advances in Horticultural Science, 20:156-161.

Metting, B.; Zimmerman, W.J.; Crouch, I. and Van Staden, J. (1990). Agronomic uses of seaweed and microalgae. In Akatsuka I (ed). Introduction to Applied phycology. SPB Academic Publishing, The Hague, 269-307.

Metzner, H.; Rau, H. and Senger, H. (1965). Untersuchungen, zur Synchronisierbarkei einzelner Pigmentmangel Mutanten von Chlorella. Planta., 65: 186-190.

Mohan, V. R.; Venkataraman Kumar, V.; Murugeswari, R. and Muthuswami, S. (1994). Effect of crude and commercial seaweed extracts on seed germination and seedling growth in Cajanus cajan L. Phykos, 33 (1\&2):47-51.

Mooney, P. A. and Van Staden, J. (1986). Algae and cytokinins. J. of Plant Physiology, 123:1-2.

Nelson,W. R. and Van Staden, J. (1984). The effect of seaweed concentrate on the growth of nutrient-stressed, greenhouse cucumbers. Horticultural Science, 19:81-82.

Pereyra-Irujo, G. A. and Aguirrezabal, L. A. N. (2007). Sunflower yield and oil quality interactions and variability: analysis through a simple simulation model. Agricultural and Forest Meteorology, 143:252-262.

Rama Rao, K. (1991). Effect of seaweed extract on Zizyphus mauratiana Lamk. J. Indian Bot. Soc., 71:19-21.

Rathore, S. S.; Chaudhary, D. R.; Boricha, G. N.; Ghosh, A.; Bhatt, B. P.; Zodape, S. T. and Patolia, J. S. (2009). Effect of seaweed extract on the growth, yield and nutrient uptake of soybean (Glycine max) under rainfed conditions. South African Journal of Botany, 75:351-355.

Russell, D. F. (1991). MSTATC. Directory crop soil science Dept. Michigan Univ. USA.

Russo, R.O.; Poincelot, R.P. and Berlyn, G.P. (1994). The use of a commercial organic biostimulant for improved production of marigold cultivars. Journal of Home Consumer and Horticulture, 1:83-93. 
Salah El Din, R. A; Elbakry, A. A.; Ghazi, S. M. and Abdel Hamid. O. M. (2008). Effect of seaweed extract on the growth and yield of Faba bean (Vicia faba L.). Egypt. J. of Phycology, 9: 25-38.

Schmidt, R. E.; Ervin, E. H. and Zhang, X. (2003). Questions and answers about biostimulants. Golf Course Management. 71:91-94.

Seiler, G. J. (1986). Analysis of the relationships of environmental factors with seed oil and fatty acid concentrations of wild annual sunflower. Field Crops Res., 15:57-72.

Siskos, Y.; Matsatsinis, N. F. and Baourakis, G. (2001). Multicriteria analysis in agricultural marketing: the case of French olive oil market. Eur. J. Oper. Res., 130:315-331.

Sivasankari, S.; Venkatesalu, V.; Anantharaj, M. and Chandrasekaran, M. (2006). Effect of seaweed extracts on the growth and biochemical constituents of Vigna sinensis. Bioresource Technology, 97:1745-1751.

Strik, W. A.; Arthur, G. D.; Lourens, A. F.; Novak O.; Strnad, M. and Staden, J. V. (2004). Changes in cytokinin and auxin concentrations in seaweed concentrates when stored at an elevated temperature. J. Appl. Phycology, 16: 31-39.

Thirumaran, G.; Arumugam, M.; Arumugam, R. and Anantharaman, P. (2009). Effect of Seaweed Liquid Fertilizer on Growth and Pigment Concentration of Abelmoschus esculentus (l) medikus. AmericanEurasian Journal of Agronomy, 2(2): 57-66.

Turan, M. and Köse, C. (2004). Seaweed extracts improve copper uptake of grapevine. Acta Agriculturae Scandinavica. Section B, Soil and Plant Science, 54:213-220.

Wang, Q.; Shi, W.Y.; Rong, F.J.; Ma, J.W.; Guan, C.H. and Jiang, L.N. (2005). The effect of the liquid seaweed extract on resisting salinity stress of cucumber. Acta-Agriculturae-Zhejiangensis, 17(5): 268-272.

Whapham, C.A.; Blunden, G.; Jenkins, T. and Wankins, S. D. (1993). Significance of betanines in the increased chlorophyll content of plants treated with seaweed extract. Applied Phycology, 5: 231-234.

Yvin, J. C. (1994). New approach to the mode of action of seaweed extract in Agriculture. Comptes-Rendus-de-l'Academie-d Agriculture de-France, 80(2):103-112.

Zodape, S. T. (2001). Seaweeds as a biofertilizer. Journal of Scientific and Industrial research New Delhi, 60(5): 378-382. 


\title{
تأثير الرش الورقى لمستخلصات من الطحالب البحرية على الانتاجية ومحتوى التري الزيث لنبات عباد الشمس الب لئس
}

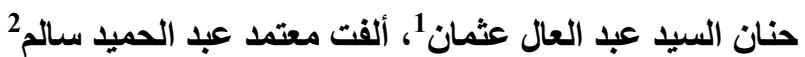

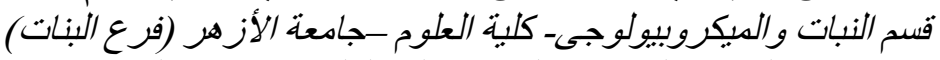

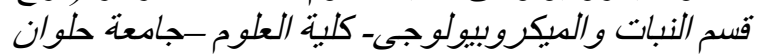

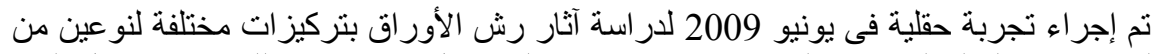

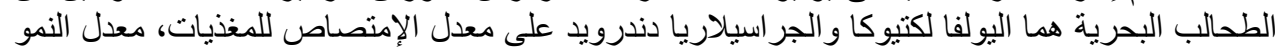

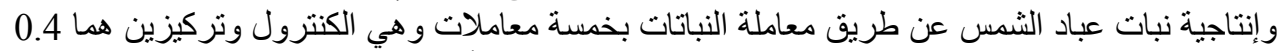

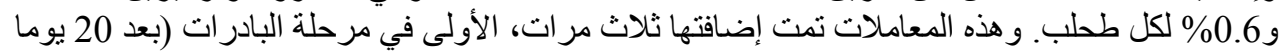

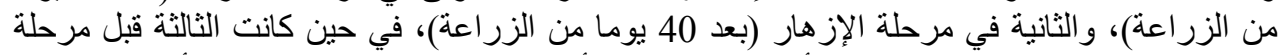

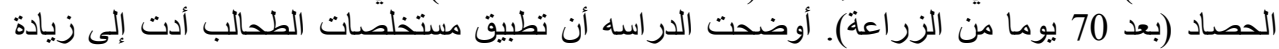

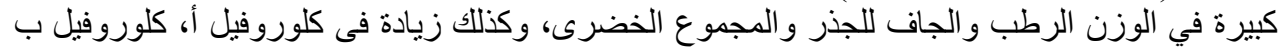

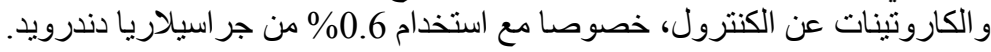

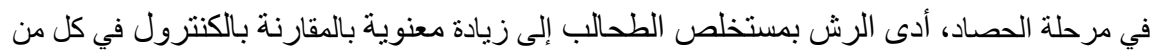

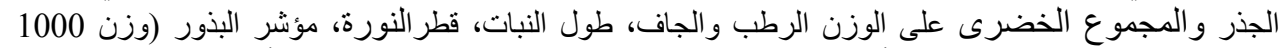

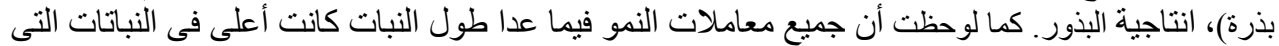
تمت معاملتها باستخدام 0.6 \% لطحلب الجر اسيلاريا دندرويد.

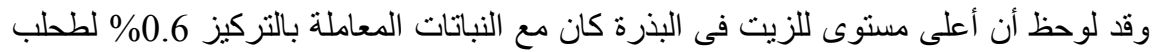

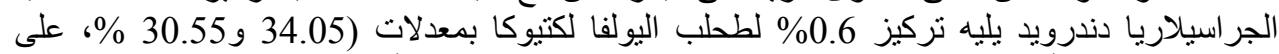

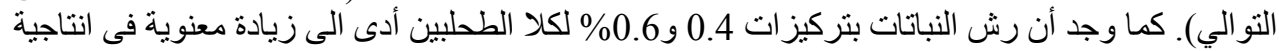

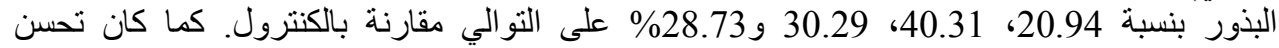

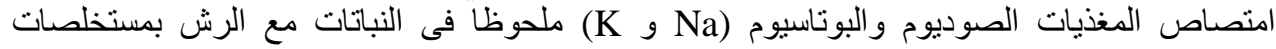

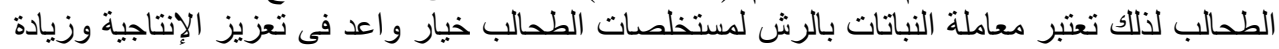
انتاج الزيت من نبات عباد الثمس التيات 